\title{
Geochemical Detection of Soil Discontinuities in a Relatively Stable Terrain: Wonu, South-West Nigeria
}

\author{
Offiong I. Akpanika \\ Department of Chemical /Petroleum Engineering, University of Uyo, Uyo Nigeria
}

\begin{abstract}
Movement of soil materials resulting in transported overburden occur in relatively stable terrains as described from the Wonu area of South-West Nigeria. The effect of such transported soils may be serious in pedogeochemical studies as they could lead to false anomalies, masked anomalies and incorrect bedrock identification during geological mapping in highly weathered terrains. Several techniques and parameters have been successfully used to detect discontinuities in soil. A lot of these are based on 'abrupt changes' expressed by a departure in depth trends mostly physical between zones of otherwise relative uniformity. This study shows that plots of bases/alumina versus silica/alumina from geochemical analysis can be used to separate the transported soil material from that of the soil formed in-situ.
\end{abstract}

Keywords: Lithologic discontinuities, pedogeochemistry, bedrock, anomalies, profile

DOI: $10.7176 /$ JNSR/9-3-02

\section{INTRODUCTION}

Modern methods of soil studies as exploration tool in prospecting for economic deposits was first used in USSR in the search for tin in the early 1930's. The success of the exercise was quickly followed by its application in geochemical surveys for copper, lead, zinc, nickel, tungsten and other metals (Levinson 1974, Hawkes and Webbs 1976). Geochemical studies of soils have also become a tool for geologic mapping of bed rock in areas with few or no outcrops and a high degree of weathering (Webb 1970, Matheis 1980, Laming and Gibbs 1982).

The principles underlying the use of soil as a geochemical sampling medium are based on the fact that during the process of soil formation, chemical components of the bed-rock become incorporated in the soil so that the elemental content of the near-surface soil reflects that of the parent rock (Bradshaw and Thompson 1982). Similarly, weathering of sub-outcropping mineralization results in metals being retained in the overlying soil and the formation of a residual soil anomaly.

The major problem posed in the use of this technique is the possibility of the displacement of geochemical anomalies either as a result of seasonal wash (Chowdhury 1982) or mass movement of soil resulting in 'transported overburden' (Michie et al 1972).

This leads to lithologic discontinuity - a situation where soils that are pedogenic and those that are geologic are encountered in the same profile. According to Arnold (1968) a lithologic discontinuity is represented by a more or less horizontal interface between two materials (a) that are separate and distinct from each other in terms of pattern of size grading, fabric, and mineralogy and (b) each of which exhibits internal unity.

Simonson (1959) had shown that the processes responsible for changes that are thought to have occurred or are currently occurring in progress in a solum can be generalized into four broad group types: additions, losses, translocations and transformations although they are not mutually exclusive. The concept that all processes operate in all soil systems and that the combination of past and present rates characterize genesis tends to unify the soil as a system. Thus within a vertical section abrupt changes in the magnitude of a property or in the pattern of variations that do not appear to belong to a general complementary relation are usually interpreted as differences related to depositional changes of materials. This problem is particularly accentuated in tectonically unstable regions. Parameters and methods that have been successfully used to detect lithologic discontinuities are shown in Table 1.

In Nigeria, believed to have been tectonically stable over long geologic period, pedogeochemisty has been used both for exporation for metallic minerals as well a bedrock mapping (Matheis 1980). Asadu and Akamigbo (1987) have discussed lithological discontinuities in soils of Eastern Nigeria. Similarly, studies of the chemistry and mineralogy of soils overlying different rock types in Southwest Nigeria show that minor movement of soils undetected physically do occur and could affect the interpretation of geochemical data obtained during exploration.

The aim of this paper is to show how such soil discontinuities could be detected through plots of bases/alumina versus silica/alumina from geochemical analysis of samples collected from a vertical profile.

\section{ENVIRONMENTAL SETTING}

Wonu, the area, of study is in South-West Nigeria and lies within the Nigerian 'Schist belt' (Fig. 1), a part of the basement complex of Nigeria. The 'belt' is made up of a number of well defined, approximately North-south trending schistose rocks that lie in synclinorial troughs separated from one another by uplift of the reworked basement. Olade and Elueze (1979) believe the rocks represent remnants of a supracrustal cover that was steeply infolded into the remobilized Archean gneisses and migmatites during the Pan-African Orogeny. 
Lithologically the Wonu area (Fig. 2) consists of gneisses and amphibolites. Lenses of talc schists occur within the area sandwiched between the gneisses and amphibolites and are probably derived from the replacement of the latter. Quartzite and quartz-rich schists form local hills and ridges. A few pegmatite occurrences have also been reported (Elueze 1977).

\section{TOPOGRAPHY AND DRAINAGE}

Wonu is a lowland area with a few hills and ridges rising up to 600 metres. The hills have gentle slopes with gradients between 1 in 5 and 1 in 10. A number of seasonal streams occur in the area and drain eastward into the Oshun River. The drainage channels are well developed and deeply entrenched in the amphibolites and gneisses.

\section{CLIMATE AND VEGETATION}

The climate is tropical with distinct wet and dry seasons. Annual rainfall ranges between $1270 \mathrm{~mm}$ and $1524 \mathrm{~mm}$. Humidity is high (about 85\%) and daily temperatures average $26^{\circ} \mathrm{C}$ (Fed. Min. of mines \& Power 1978). Tropical rain forest with tall evergreen trees and understorey shrubs originally covered the area. However, increased population and concomitant land use has resulted in over $60 \%$ of the forest being cleared for cash crop farms and settlement.

\section{SAMPLING AND ANALYTICAL PROCEDURES:}

The soils in the area fall into the red/yellow podzol category with a dark grey solum clearly distinct from the brown A horizon (Mclean and Gribble 1979). They are generally coarse at the top of profiles and become clayey at depths below 1 metre.

The profile studied (Fig.3) is derived from talc schist and is representative of most soils in the area except for a few profiles derived from amphibolite. In these, the A horizon extends to $46 \mathrm{~cm}$ below the surface and a $B_{1}$ and $\mathrm{B}_{2}$ horizon is present.

Samples weighing about $5 \mathrm{~kg}$ each were collected starting from the bottom of the profile and labelled TPS1 to TPS9 (See Fig.3).

The $\mathrm{pH}$ of the soil samples was measured in a 1:10 soil: water suspension after allowing it to stand for four hours. For the granulometric analysis, $100 \mathrm{mg}$ of air-dried and gently disaggregated sample was agitated with a Ro-tap machine for 15 minutes. Only four size fractions were obtained by sieving.

$\begin{array}{lll}\text { Aperture Size } & \text { Mesh. No. } & \text { Remark } \\ 500 \mathrm{~mm} & 32 & \text { Coarse } \\ 250 \mathrm{~mm}-.500 \mathrm{~mm} & 32-60 & \text { Medium } \\ 125-250 \mathrm{~mm} & 60-115 & \text { Fine } \\ 125 \mathrm{~mm} & 115 & \text { Very Fine }\end{array}$

The major and minor elements in the bulk samples were determined by wet chemical methods as outlined by Riley (1958). Colorimetric measurement for $\mathrm{Si}, \mathrm{Al}$, Ti and Fe was carried out on a Pye Unicam 300 colorimeter. $\mathrm{Mg}, \mathrm{Mn}, \mathrm{Ca}, \mathrm{Fe}, \mathrm{Ni}, \mathrm{Co}, \mathrm{Cu}$ and $\mathrm{Zn}$ were determined on a Perkin Elmer 300 Atomic Absorption Spectrophometer with a precision of \pm 20 percent of 95 percent confidence limit. Flame emission spectrometer was used to determine $\mathrm{Na}$ and $\mathrm{K}$ concentration.

\section{RESULTS}

Grain size distribution in the samples collected shows a marked increase in the very coarse and pebble fractions in the A and B horizons compared to the relatively fine grained $\mathrm{C}$ horizons (Fig. 4). The soil is weakly acidic with PH ranging from 5.8 at the bottom to 6.4 at the top of the profile (Table 1). The variation of chemical components in the profile is shown in Tables 1 and 2 and Fig. 5.

\section{DISCUSSION}

Ligthological discontinuities have long been known from the early days of soil analysis (Simonson 1959). The study of these features and the development of a set of guidelines directed towards this accurate detection have great scientific values.

Different parameters have been used successfully to detect discontinuity in soils. Depth functions involving clay-free particles size data, especially the coarser sands and fine silt fractions have been found to be the most indicators of the discontinuity (Schaetzl 1998).

The upper (coarse) section of the profile studied exhibits characteristics of immature soil and is believed to be a result of transportation of materials from a nearby source. This is supported by the sharp rise of $\mathrm{Si}_{2}$ content from $46 \%$ at the base of the saprolite zone to $75 \%$ in the topsoil. $\mathrm{Mg} 0$ on the other hand shows a marked depletion.

Translocation, mixing processes and transformations leading to intense chemical alteration within the soil profile sometimes tend to blur or obliterate lithologic discontinuities especially where the discontinuity is of small magnitude. Variations of some properties, in such cases, can be so reduced in intensity that consistent detection of 
a discontinuity becomes difficult (Oertel and Giles (1966). Thus Schaetzl (1998) advised that the ratio of two parameters has an advantage over a depth function of one of the same parameters. This concept of ratios has been applied in this study. Although $\mathrm{Al}_{2} \mathrm{O}_{3}$ is relatively enriched in the soil it shows a fairly gradual depletion from $12 \%$ at the saprolit to $8 \%$ in the top soil. Consequently ratios of bases:alumina and silica:alumina were determined. Plots of these ratios (Fig.6) divide the samples into two distinct populations; Samples TPS 1-6 representing the population formed insitu from the underlying rock and TPS 7-9, the other population from an extraneous source.

Also the trace element relations with the molar ratios show that the trace element Vs bases/alumina plot (Fig.7) is also informative in determining the homogeneity or otherwise of a profile.

Soil samples for chemical analysis are normally obtained close to the surface just below the o horizon most often about $10-30 \mathrm{~cm}$ below the surface. If discontinuities in the soil profile are undetected, geochemical studies from such soils may be greatly in error since chemical changes between parent rock and soil are usually presumed to be a function of weathering.

The absence of very high hills and cliffs, steeply dipping strata, cleavage planes and the lack of weak formations preclude the possible occurrence of either landslides, slumping or any other form of mass movement of soil within the area. Rather a gradual movement over a period of time is indicated.

\section{CONCLUSION}

Soil erosion is thought to be responsible for the transport of surficial soil materials in Wonu, South-West Nigeria. Such transported soil could lead to false geochemical anomalies, masked anomalies and incorrect bed-rock identification during geological mapping in highly weathered terraines.

The study in Wonu area has shown that soil discontinuities could be detected by chemical analysis of the profile and particularly by plots of the molar ratios of bases/alumina vs silica alumina.

It is suggested that such a study to determine soil homogeneity should form an essential aspect of reconnaissance studies whenever soil is to be used as used a sample medium in geochemical investigations.

\section{REFERENCES}

Akpanika, O. I. (1984) Geochemical and Mineralogical Studies of Soils overlying a Talc Schist and Amphibolite in Wonu, South West Nigeria. M.Sc. Thesis, University of Calabar (unpubl.) 114p.

Alexander, J. B., Beavers, A. H. and Johnson, P. R. (1962) Zirconium Content of Coarse Silt in Loess and Till of Wisconsin Age in Northern Illinois. Soil Sci. Soc. Am. Proc. 26:189-191.

Arnold, R. W. (1968) Pedological Significance of Lithological Discontinuities Trans. 9 ${ }^{\text {th }}$ Intl. Congress Soil Science (Adelaide) 4:595-603.

Asadu, C. I. A. and Akamigbo, F. O. R. (1987) The Use of Abrupt Changes in the Selected Soil Properties to Assess Lithological Discontinuities in Soils of Eastern Nigeria. Pedologie 37:43-56.

Asady, G. H. and Whiteside, E. P. (1982) Composition of a Conover-Brookston Map Unit in South Eastern Michigan. Soil Sci. Soc. Am. J. 46:1043-1047.

Asamoa, G. K. and Protz, R. (1972) Influence of Discontinuities in Particle Size on the Genesis of two Soils of the Honeywood Catena. Can. J. Soil. Sc. 52:457-511.

Barnhisel, R. I., Bailey, H. H., and Matondang, S. (1971) Loess Distribution in Central and Eastern Kentucky. Soil Sci. Soc. Am. Proc. 35.483-487.

Beshay, N. F. and Sallam, A. S. (1995) Evaluation of Some Methods for Establishing Uniformity of Profile Parent Material. Arid Soil Res. Rehabil. 9:63-72.

Bigham, J. M., Smeck, N. E. Norton, L. D., Hall, G. F. and Thompson, M. L. (1991) Lithology and General Stratigraphy of Quaternacy Sediments in a Section of Teays River Valley of Southern Ohio. In Geology and Hydrogeology of the Teays-Mahomet Bednock Valley System. W. N. Melhorn and J. P. Kempton (eds). Geol. Soc. Am. Spec. Paper 258. Boulder, CO. pp 19-29.

Birkeland, P. W. (1974) Pedology, Weathering and Geomorphological Research. Oxford University Press. London $258 \mathrm{p}$.

Borchardt, G. A., Hole, F. D. and Jackson, M. L. (1968) Genesis of Layer Silicates in Representative Soils in Glacial Landscape of Southeastern Wiscoasin. Soil Sci. Am. Proc. 33:399-403.

Bradshaw, P. M. D. and Thompson, I. (1982) Geochemical Exploration for Mineral Deposits in Tropical Rain Forest Environment p 62-74. In Hidden Wealth: Mineral Exploration Techniques in Tropical Forest Areas. D. J. C. Laming and A. K. Gibbs (eds.) AGID Report No. 7.

Busacca, A. J. and Singer, M. J. (1989) Pedogenesis of a Chronosequence in the Sacramento Valley, California, USA. II Elemental Chemistry of Silt Fractions. Geoderma 44:43-75.

Cabrera-Martinez, F., Harris, W. G., Carlilse, V. W. and Collins, M. E. (1989) Evidence for Clay Translocation in Coastal Plain Soils with Sandy/Loamy Boundaries. Soil Sci. Soc. Am. J. 53:1108-1114.

Caldwell, R. E. and Pourzad, J. (1974) Characterization of Selected Paleudults in West Florida. Soil Crop Sci. Soc. Pla. Proc. 33:143-147. 
Chapman, S. L. and Horn, M. E. (1968) Parent Material Uniformity and Origin of Silty Soils in Northwest Arkansas Based on Zirconium-Titanium Contents. Soil Sci. Soc. Am. Proc. 32:265-271.

Chowdhury, M. K. (1982) Mineral Exploration Strategies in Tropical Rain Forests of India pp 38-44. In Hidden Wealth: Mineral Exploration Techniques in Tropical Forest Areas D. J. C. Laming and A. K. Gibbs (eds.) AGID Report No 7.

Cremeens, D. L. and Mokma, D. L. (1986) Argillic Horizon Expression and Classification in the Soils of Two Michigan Hydrosequences. Soil Sc. Am. J. 50:1002-1007.

Elueze, A. A. (1977) Geology and Geochemical Studies in the Ilesha Gold Belt. M. Phil. Thesis, University of Ibadan (Unpubl.).

Fine, P., Singer, M. J. and Verosub, K. L. (1992) Use of Magnetic Susceptibility Measurements in Assessing Soil Uniformity in Chronosequence Studies. Soil Sc. Am. J. 56:1195-1199.

Fiskell, J. G. A. and Caslisla, V. W. (1963) Weathering of some Florida Soils. Soil Crop Soc. Fla. Proc. 23:32-44.

Follmer, L. R. (1982) The Geomorphology of the Sangamon Surface: Its Spatial and Temporal Attributes. In Space and Time in Geomorphology C. Thorn (ed.) Allen and Unwin, Boston pp 117-146.

Foss, J. E., Fanning, D. S., Miller, F. P. and Wagner, D. P. (1978) Loess Deposits of the Eastern Shore of Maryland. Soil Sc. Soc. Am. J. 42.329-334.

Gamble, E. E., Daniels, R. B. and McCracken, R. J. (1969) A2 Horizons of Coastal Plain Soils Pedogenic or Geologic Origin. Southeastern Geol. 11:137-152.

Hartgrove, N. T. Ammons, J. T., Khiel, A. R. and O’Dell, J. D. (1993) Genesis of Soils on Two Stream Terrace Levels on the Tennessee River. Soil Surv. Horiz. 34:78-88.

Hawkes, H. E. (1954) Geochemical Prospecting Investigations in Nyeba lead-Zinc District of Nigeria. Bull US Geol. Surv. 1000-F pp 225-355.

Ige, O. A. (1982) Mineralogical and Chemical Studies of Talc Bodies in Wonu, Apomu Area, Western Nigeria, in Relation to Their Industrial Properties. M.Sc. Thesis Univ. of Ibadan (unpubl.) 94p.

Karathanasis, A. D. and Macneal. B. R. (1994) Evaluation of Parent Material Uniformity Criteria in Loessinfluenced Soils of West-Central Kentucky. Geoderma 64:73-92.

Khangarot, A. S., Wilding, L. P., and Hall, G. F. (1971) Composition and Weathering of Loess Mantled Wisconsin and Illionianage Terraces in Central Ohio. Soil Sci. Soc. Am. Proc. 35:621-626.

Kuzila, M. S. (1995) Identification of Multiple Loess Units Within Modern Soils of Clay Country, Nebraska. Geoderma 65:45-57.

Laming, D. J. C. and Gibbs, A. K. (eds) (1982) Hidden Wealth: Mineral Exploration Techniques in Tropical Forest Areas. AGID Report No. 7220 p.

Langohr, R., Scopp, C. O. and Van Wambeke, A. (1976) The use of Comparative Particle Size Distribution Index for the Numerical Classification of Soil Parent Materials: Application to Mollisols of the Argentine Pampa. Geoderma 15:305-312.

Matheis, G. (1980) Secondary Geochemical Dispersion and Bedrock Reflection in the Tropical Rain Forest. Brzmetall. 33:180-185.

Mclean, A. C. and Gibble, C. D. (1979) Geology for Civil Engineers. George Allen and Unwin, London. 310p.

Meixner, R. E. and Singer, M. J. (1981) Use of a Field Morphology Rating System to Evaluate Soil Formation and Discontinuities Soil Sci. 131:114-123.

Michie, U. Md., Gallagher, M. J. and Simpson, A. (1972) Detection of Concealed Mineralization in Northern Scotland. In Geochemical Expl. M. J. Jones (ed.) Pro $4^{\text {th }}$ Intl. Geochem Expl. Symposium.

Norton, L. D. and Hall, G. F. (1985) Differetiation of Lithologically Similar Soil Parent Materials. Soil Sci. Soc. Am. J. 49:409-414.

Oertel, A. C. and Giles, J. B. (1966) Quantitative Study of a Layered Soil. Aust. J. Soil Res. 4:19-28.

Olade, M. A. and Elueze, A. A. (1979) Petrochemistry of the Ilesha Amphibolite and Precambrian Crustal Evolution in the Pan-African Domain of S. W. Nigeria Precam. Res. 8:308-318.

Onweremadu, E. U. (2007) Pedology of Near Gully Sites and its Implications on the Erodibility of Soils in Central South Eastern Nigeria. Res. J. Env. Sci. 1:71-76.

Phillips, J. D. and Loiz, C. (2008) Origin and Implication of Soil Layering Earth Sci. Rev. 89:144-155.

Pourjabbar, A. and Hezarkhani (2006) Heavy Metal Prospecting: A Complementary Method for Geochemical Exploration: A Case Study in Sarab, Iran. $6^{\text {th }}$ Intl. Scientific Conf. SGEM June 12-16. Conf. Pro. Vol. 1 221232.

Price, T. W., Blevins, R. L., Barnhisel, R. I. and Bailey, H. H. (1975) Lithologic Discontinuities in Loessial Soils of Southwestern Kentucky. Soil Sci. Soc. Am. Proc. 39:94-98.

Raad, A. T. and Protz, R. (1971) A New Method for the Identification of Sediment Stratification in Soils of the Blue Spring Basin, Ontavio. Geoderma 6:23-41.

Ransom, M. D., Smeck, N. E. and Bigham, J. M. (1987) Stratigraphy and Genesis of Polygenetic Soils on the Illinoian Till Plain of Southeastern Ohio. Soil Sci. Soc. Am. J. 51:135-141. 
Riley, J. P. (1958) The Rapid Analysis of Rocks and Minerals. Anal Chim. Acta. 19:413-428.

Roberts, R. O. (1953) Geochemical Investigation in Nigeria in 1948 and 1949. Col. Geol. Min. Res. 3:347-357.

Rutledge, E. M. Holowaychuck, N., Hall, G. F. and Wilding, L. P. (1975a) Loess in Ohio in Relation to Several Possible Source Areas I. Physical and Chemical Properties. Soil Sci. Soc. Am. Proc. 39:1125-1132.

Rutledge, E. M., Holowaychuck, N., Hall, G. F and Wilding. L. D. (1975b) Loess in Ohio in Relation to Several Possible Source Areas II Elemental and Mineralogical Composition. Soil Sci. Soc. Am. Proc. 39:1133-1139.

Santos, M. C. D., Arnaud, R. J. St., Anderson, D. W. (1986) Quantitative Evaluation of Pedogenic Changes in Boralfs (Gray Luvisols) of East Central Saskatchewan. Soil Sci. Soc. Am. J. 50:1013-1019.

Schaetzl, R. J. (1992) Texture. Mineralogy and Lamellae Development in Sandy Soils in Michigan. Soil Sci. Soc. Am. J. 1538-1545.

Schaetzl, R. J. (1996) Spodosol-Alfisol Intergrades; Bisequal Soils in NE Michigan USA. Geodorma 74:23-47.

Scaetzel, R. J. (1998) Lithologic Discontinuities in Some Soils on Drumlins: Theory, Detection and Application. Soil Sci. 163:570-590.

Singer, M. J. and Fine, P. (1989) Pedogenic Factors Affecting Magnetic Susceptibility in Northern Californian Soils. Soil Sci. Soc. Am. J. 53:1119-1127.

Smith, H. and Wilding, L. P. (1972) Genesis of Argilic Horizons in Ochraqualfs Derived from Fine Textured Till Deposits of Northwestern Ohio and Southeastern Michigan. Soil Sci. Soc. Am. Proc. 36:808-815.

Washez, W. E. and Collins, M. E. (1988) Genesis of Adjascent Morphologically Distinct Soils in Northwest Florida. Soil Soc. Am. J. 52:191-196.

Webb, J. S. (1970) Some Geological Application of Regional Geochemical Reconnaissance. Proc. Geol. Assoc. $81: 585-594$

TABLE 1: Some parameters used successfully to detect lithologic discontinuities in soils

\begin{tabular}{cl}
\hline Indicator & \multicolumn{1}{c}{ References } \\
\hline Presence, absence or change in the content of a mineral & $\begin{array}{l}\text { Barnhisel et al. 1971, Raad and Protz 1971, Karathanasis } \\
\text { and } \\
\text { Macneal 1994, Kuzila 1995. }\end{array}$
\end{tabular}

Presence or absence of a detrital fossil

Content of one or more resistant minerals in a silt fraction

Content of one or more resistant minerals in a sand fraction

Elemental composition or abundance in a sand fraction

Elemental composition or abundance in a silt fraction

Elemental composition of the entire non-clay fraction Heavy mineral content

Clay mineralogy

Magnetic susceptibility

Content of coarse fragments

Total sand content, content of a sand fraction, or mean sand size

Total silt content or content of silt fraction

Clayfree sand or a clayfree sand fraction

A clayfree and carbonate-free sand fraction Clayfree silt or a clayfree silt fraction

Karathanasis and Macneal 1994

Chapman and Horn 1968, Rutledge et al. 1975b

Chapman and Horn 1968, Washer and Collins 1988

Arnold 1968

Alexander et al. 1962, Barnhisel et. al 1971, Foss et al. 1978.

Norton and Hall 1985, Ransom et al. 1987, Karathanasis and Macneal 1994

Oertel and Giles 1966

Chapman and Horn 1968, Khangarot et al. 1971, Caberera-

Martinez et al. 1989.

Follmer 1982, Nzila 1995

Singer and Fine 1989, Fine et al., 1992.

Follmer 1982, Arnold 196t8, Raad and 1971, Asamoa and Protz 1972, Meixner and Singer 1981, Schaetzl 1996

Oertel and Giles 1966, Arnold 1968, Borchardt et al. 1968, Gamble et al. 1969, Caldwell and Pourzad 1974, Meixner. and Singer 1981, Follmer 1982, Schaetzl 1992.

Oertel and Giles 1966, Caldwell and Pourzad 1974, Price et. al 1975, Meixner and Singer 1981, Follmer 1982.

Washer and Collins 1988, Busacca 1989, Buasscca and Singer 1989, Karathanasis and Macneal 1994, Schaetzl 1996.

Raad and Protz 1971.

Chapman and Horn 1968, Barnhisel et al. 1971, Asamoa and Protz 1972, price et al. 1975a,Washer and Colins 1988, Busacca 1989, Busacca and Singer, 1989, Karathanasis and Macneal 1994, Schaetzl 1996.

A clayfree and carbonate-free silt fraction Any one of a number of fine earth fractions between 20 and $500 \mu \mathrm{m}$

Raad and Protz 1971.

Langohr et al. 1976, Santos et al. 1986. 
Ratio of one sand fraction to another

Ratio of one silt fraction to another (in some cases, clayfree)

Ratio of sand/silt or silt/sand (in some cases, clayfree)

Ratio of two minerals in a sand fraction

Ratio of two minerals in a silt fraction

Ratio of an element to a resistant mineral in the silt + sand fraction

Ratio of two or more elements in a sand fraction

Ratio of two or more elements in a silt fraction

Formulas involving particle size fractions:

Uniformity Value

Comparative particle Size Distribution Index
Fiskell and Carlisle 1963, Oertel and Giles 1966, Washer and Collins 1988, Cabreera-Martinez et al, 1989, Hartgrove et al. 1993, Beshay and Sallam 1995.

Follmer 1982, Kuzila 1995.

Chapman and Horn 1968, Raad and Protz 1971, Smith and Wilding 1972, Asady and Whiteside 1982, Busacca 1989, Busacca and Singer 1989.

Chapman and Horn 1968, Beshay and Sallam 1995

Price et al. 1975, Follmer 1982, Busacca and Singer 1989, Bigham et al. 1991.

Santos et al. 1986

Smith and Wilding 1972,

Smith and wilding 1972, Foss et al. 1978, Bigham et al. 1991, Karathanasis and Macneal 1994.

Cremeens and Mokma 1986

Langohr et al. 1976.

Table 2: Profile Distribution of $\mathrm{pH}$ and the Molar Ratios Silica: Alumina and Bases: Alumina:

\begin{tabular}{|c|c|c|c|}
\hline Sample No. & $\mathrm{pH}$ & Silica: Alumina & *Bases : Alumina \\
\hline TPS 1 & 5.8 & 6.55 & 1.75 \\
2 & 6.2 & 5.28 & 1.64 \\
3 & 6.2 & 5.04 & 1.29 \\
4 & 6.1 & 6.26 & 1.80 \\
5 & 6.2 & 7.26 & 1.92 \\
6 & 6.1 & 8.65 & 1.68 \\
7 & 6.3 & 11.15 & 0.52 \\
8 & 6.3 & 15.85 & 0.07 \\
9 & 6.4 & 15.18 & 0.08 \\
\hline
\end{tabular}

*Bases: alumina calculated as $\left(\mathrm{K}_{2} \mathrm{O}+\mathrm{Mg} 0\right) / \mathrm{Al}_{2} \mathrm{O}_{3}$

Table 3: Chemical Composition of the Soil Profile

\begin{tabular}{|l|c|c|c|c|c|c|c|c|c|c|}
\hline & $\begin{array}{c}\text { Average Chemical } \\
\text { Composition of Rock* }\end{array}$ & TPS1 & 2 & 3 & 4 & 5 & 6 & 7 & 8 & 9 \\
\hline $\mathrm{SiO}_{2}$ & 57.80 & 46.8 & 45.95 & 42.00 & 44.53 & 45.74 & 49.78 & 59.53 & 72.32 & 74.74 \\
$\mathrm{Al}_{2} \mathrm{O}_{3}$ & 1.53 & 12.15 & 12.53 & 14.23 & 12.44 & 10.73 & 9.87 & 9.10 & 7.82 & 8.45 \\
$\mathrm{Fe}_{2} \mathrm{O}_{3}$ & 2.06 & 10.64 & 11.47 & 15.85 & 12.26 & 15.65 & 17.32 & 16.87 & 9.88 & 5.54 \\
$\mathrm{FeO}$ & 1.20 & 1.20 & 1.04 & 0.87 & 1.16 & 1.01 & 0.40 & 0.28 & - & - \\
$\mathrm{MgO}$ & 28.38 & 8.27 & 7.88 & 7.15 & 8.67 & 7.94 & 6.36 & 1.78 & 0.06 & 0.15 \\
$\mathrm{CaO}$ & 5.00 & - & - & - & - & - & - & - & - & - \\
$\mathrm{Na}$ & 0.11 & 0.08 & 0.08 & 0.07 & 0.05 & 0.10 & 0.05 & 0.05 & 0.05 & 0.04 \\
$\mathrm{~K}_{2} \mathrm{O}$ & 0.19 & 0.13 & 0.08 & 0.10 & 0.12 & 0.14 & 0.16 & 0.33 & 0.29 \\
$\mathrm{LOI}$ & 3.38 & 20.64 & 20.11 & 11.78 & 20.57 & 18.47 & 15.73 & 11.89 & 9.22 & 10.37 \\
\hline Total & $\mathbf{9 9 . 6 6}$ & $\mathbf{9 9 . 8 9}$ & $\mathbf{9 9 . 4 1}$ & $\mathbf{9 9 . 0 3}$ & $\mathbf{9 9 . 7 8}$ & $\mathbf{9 9 . 7 6}$ & $\mathbf{9 9 . 6 5}$ & $\mathbf{9 9 . 6 6}$ & $\mathbf{9 9 . 6 8}$ & $\mathbf{9 9 . 8 8}$ \\
\hline $\mathrm{Ni} * *$ & 850 & 99 & 75 & 65 & 87 & 85 & 111 & 79 & 69 & 82 \\
$\mathrm{Co} * *$ & 75 & 54 & 60 & 51 & 70 & 72 & 66 & 71 & 48 & 45 \\
$\mathrm{Cu} * *$ & - & 30 & 25 & 21 & 26 & 42 & 36 & 29 & 20 & 22 \\
$\mathrm{Zn} * *$ & 88 & 95 & 100 & 110 & 90 & 200 & 140 & 130 & 62 & 120 \\
\hline
\end{tabular}

*Average chemical composition of analysis of 4 samples of Talc schist collected within the study area.

** Results in ppm. 


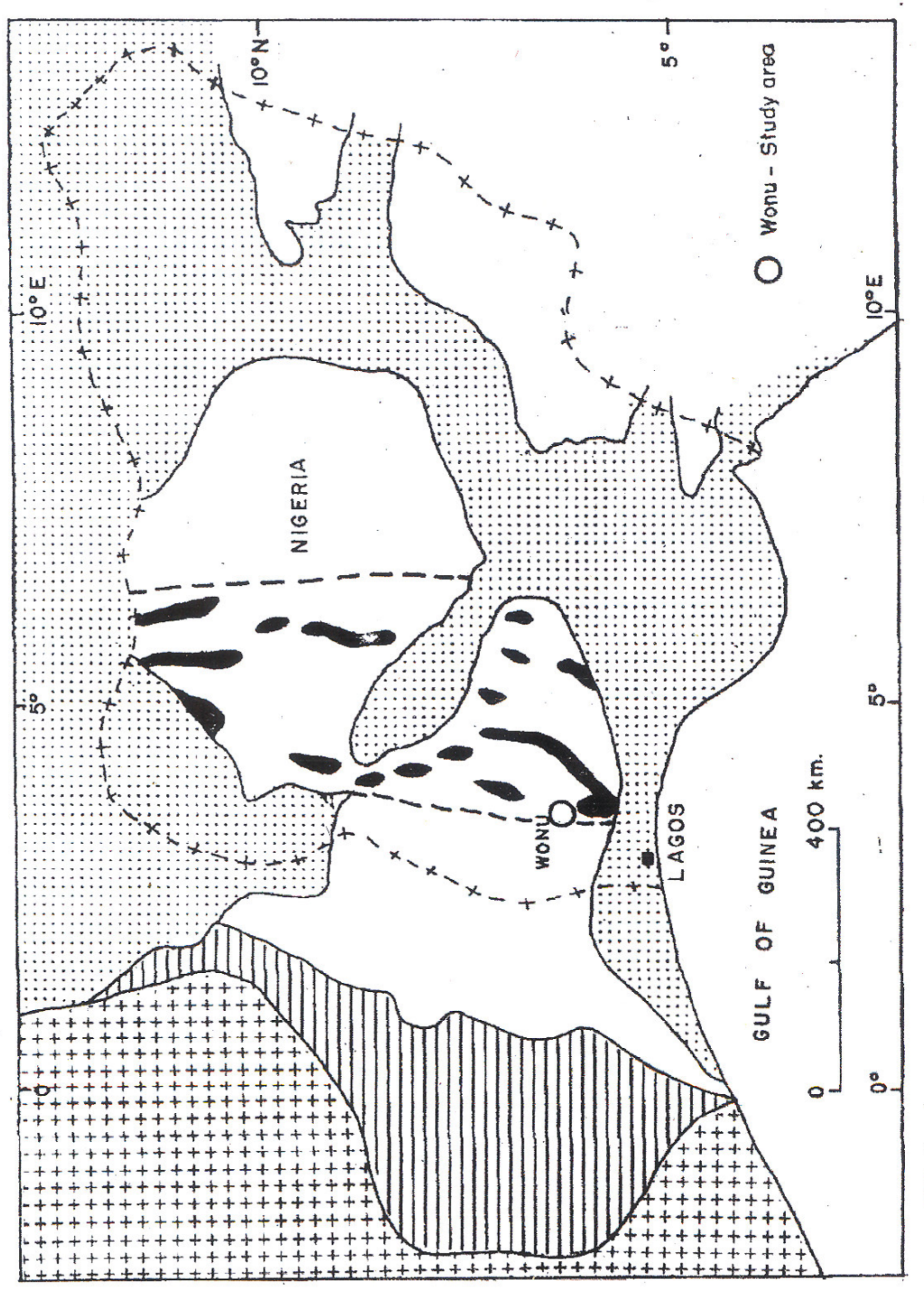




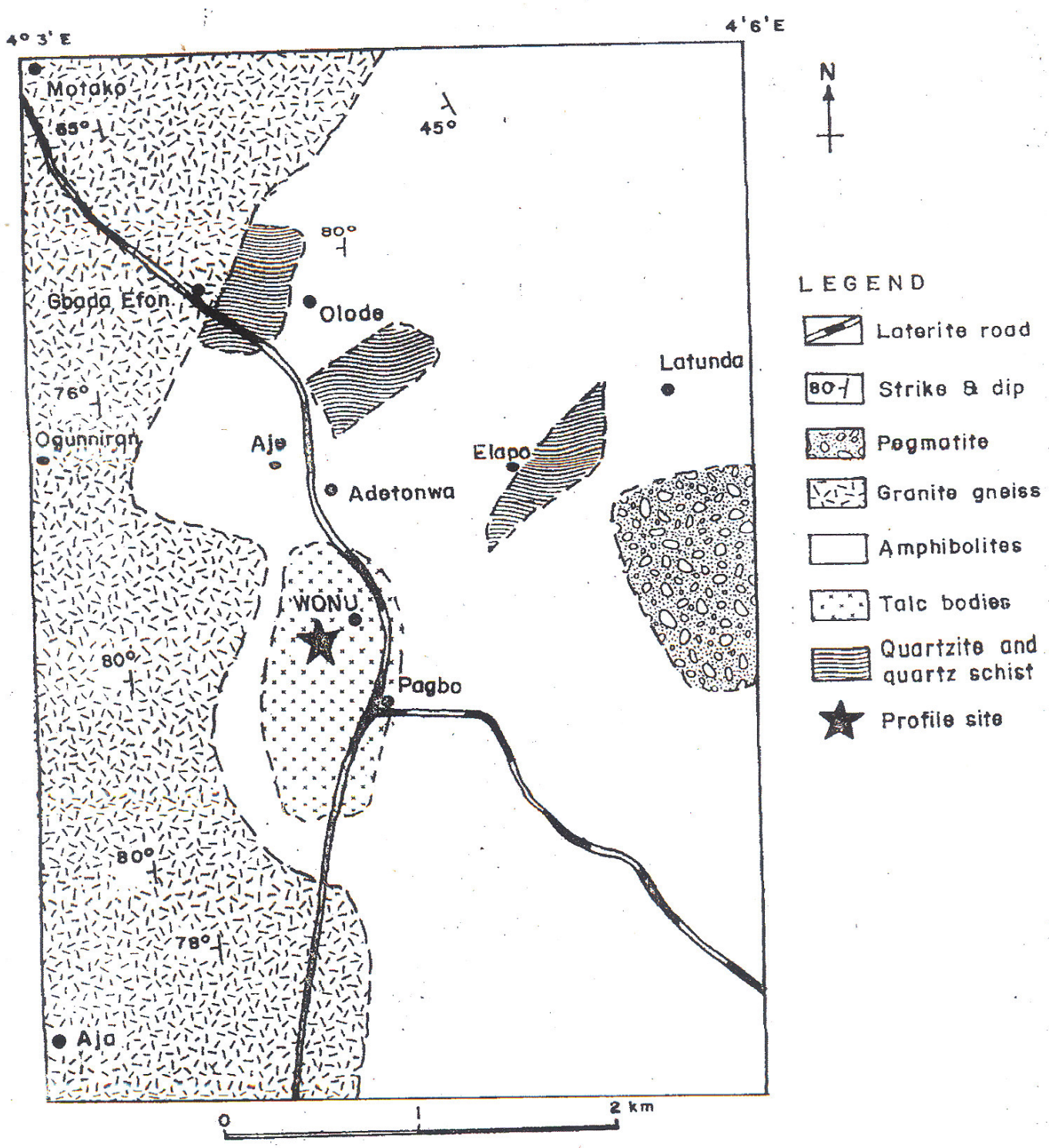

Fig. 2 Detailed geologic map of Wonu, (after 198,1982 ): 


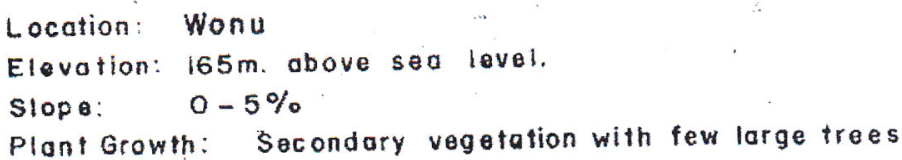

o

A

B

O) Dark orey to black humus soil

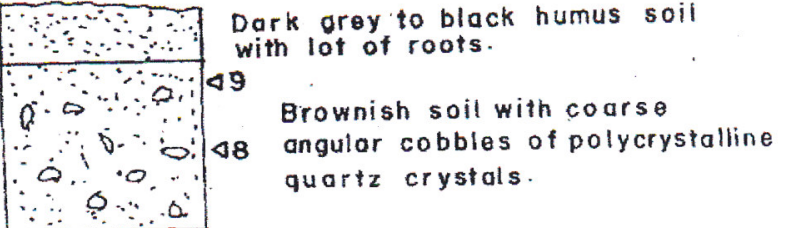
$\Delta T$ Brownish fine to medium grained $\because \because \because 30$ soil.

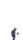

C

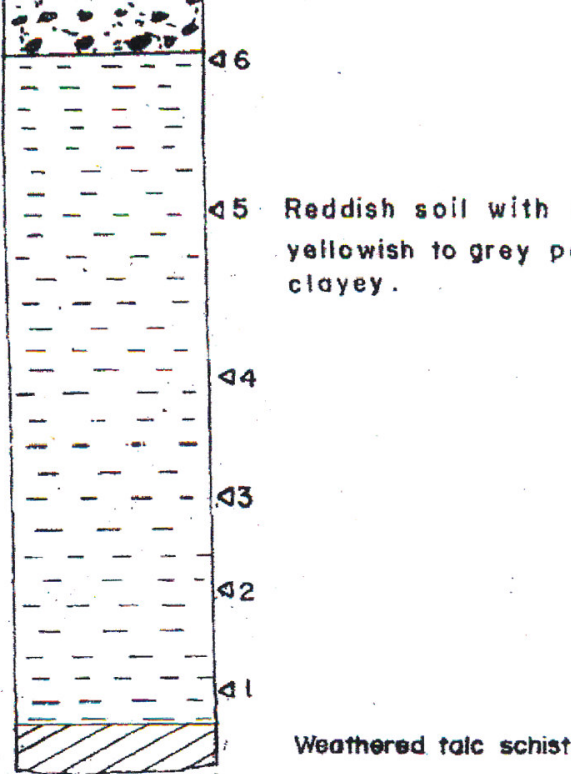

- Sampling point and number.

Fig. 3 Description of Soil profile over Tak Schist. 


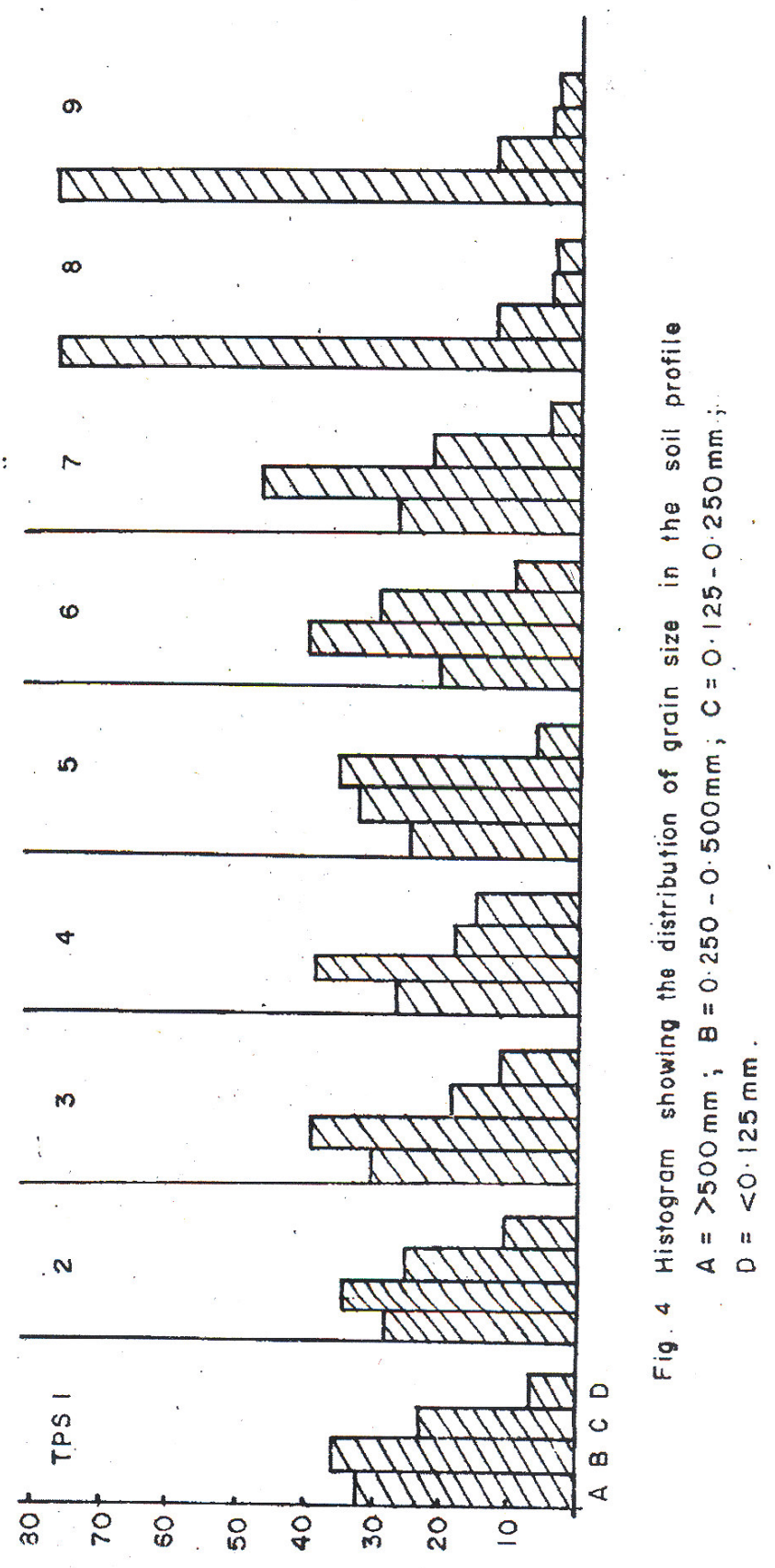



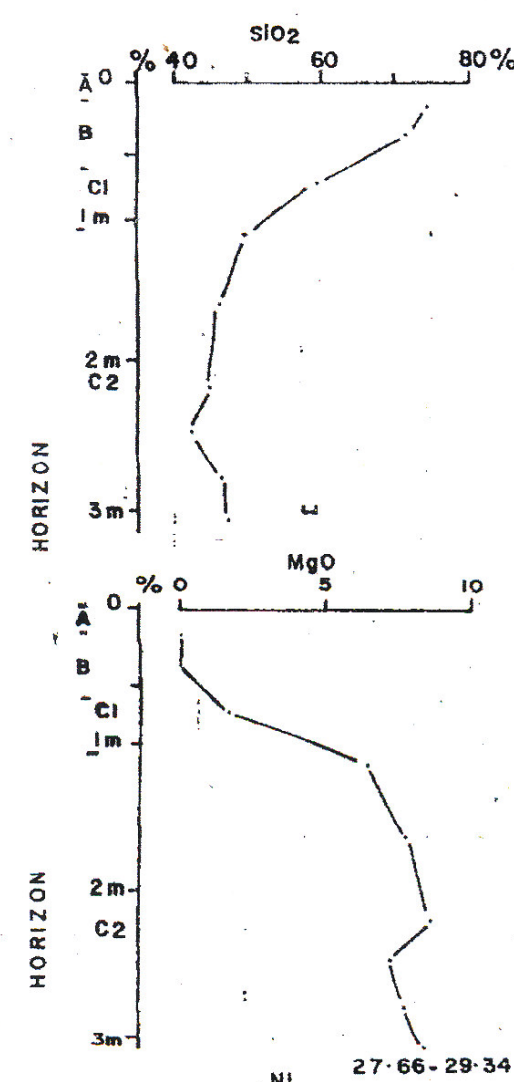

10
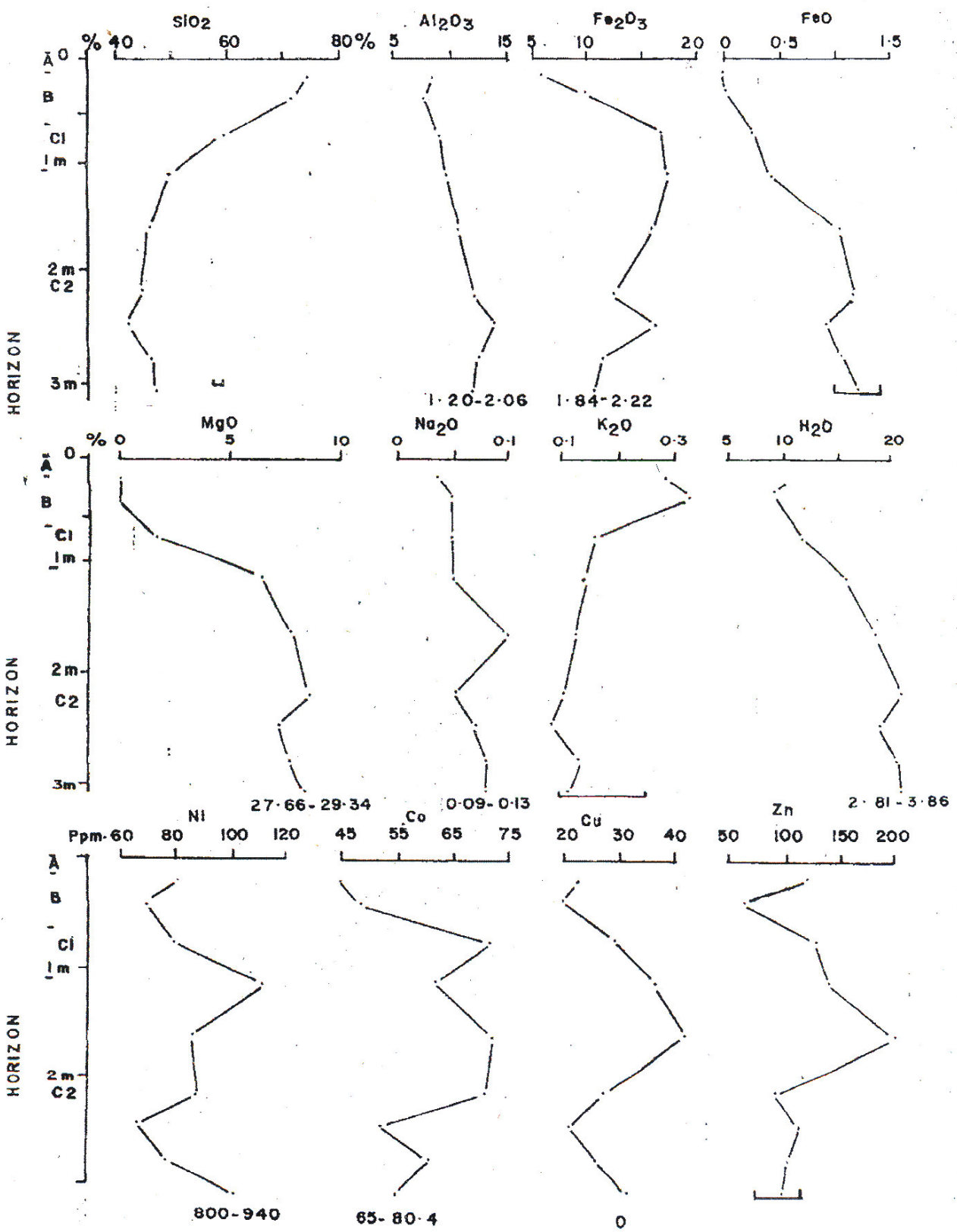

Flo. 5 Vorlation in chemical composition with depth in soil overlying talc schist, Ronge of bulk chemistry of rook indlcated by bars or figuros. 


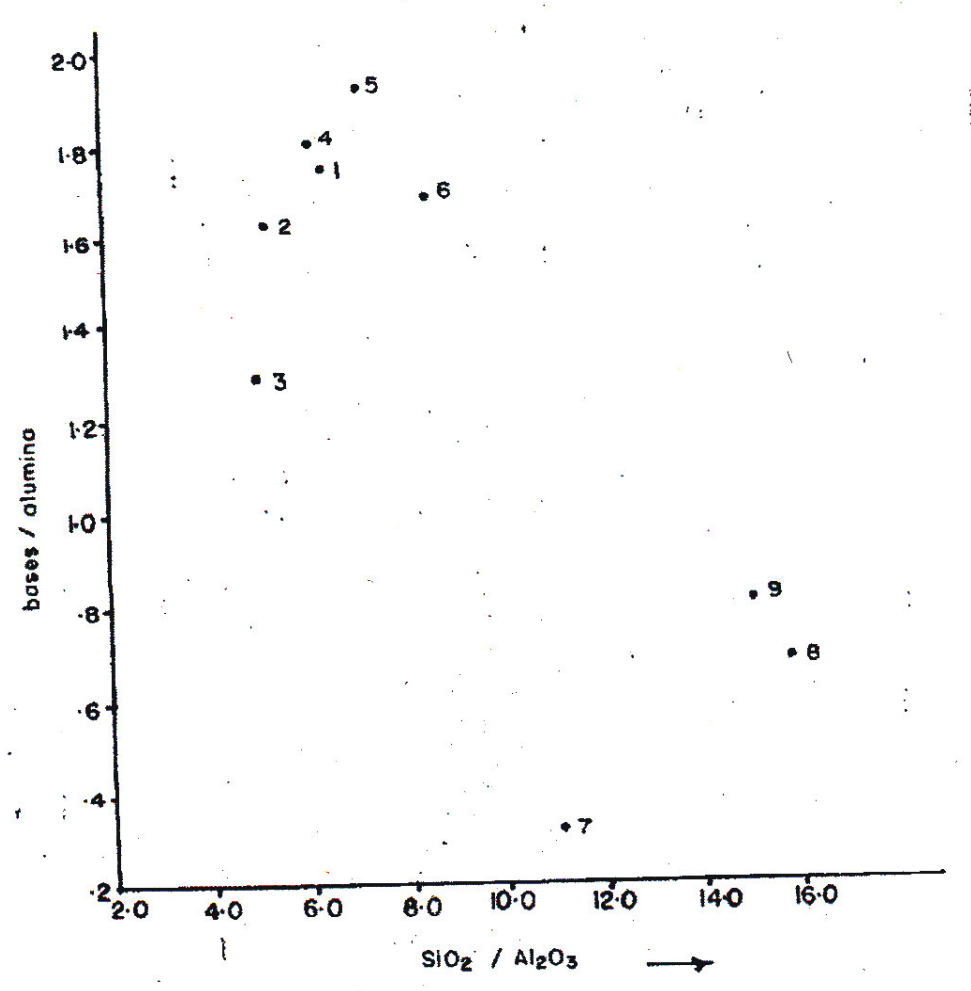

Fiq. 6 Plots of bases $/$ alumino ys silico / alumina rotlo. 


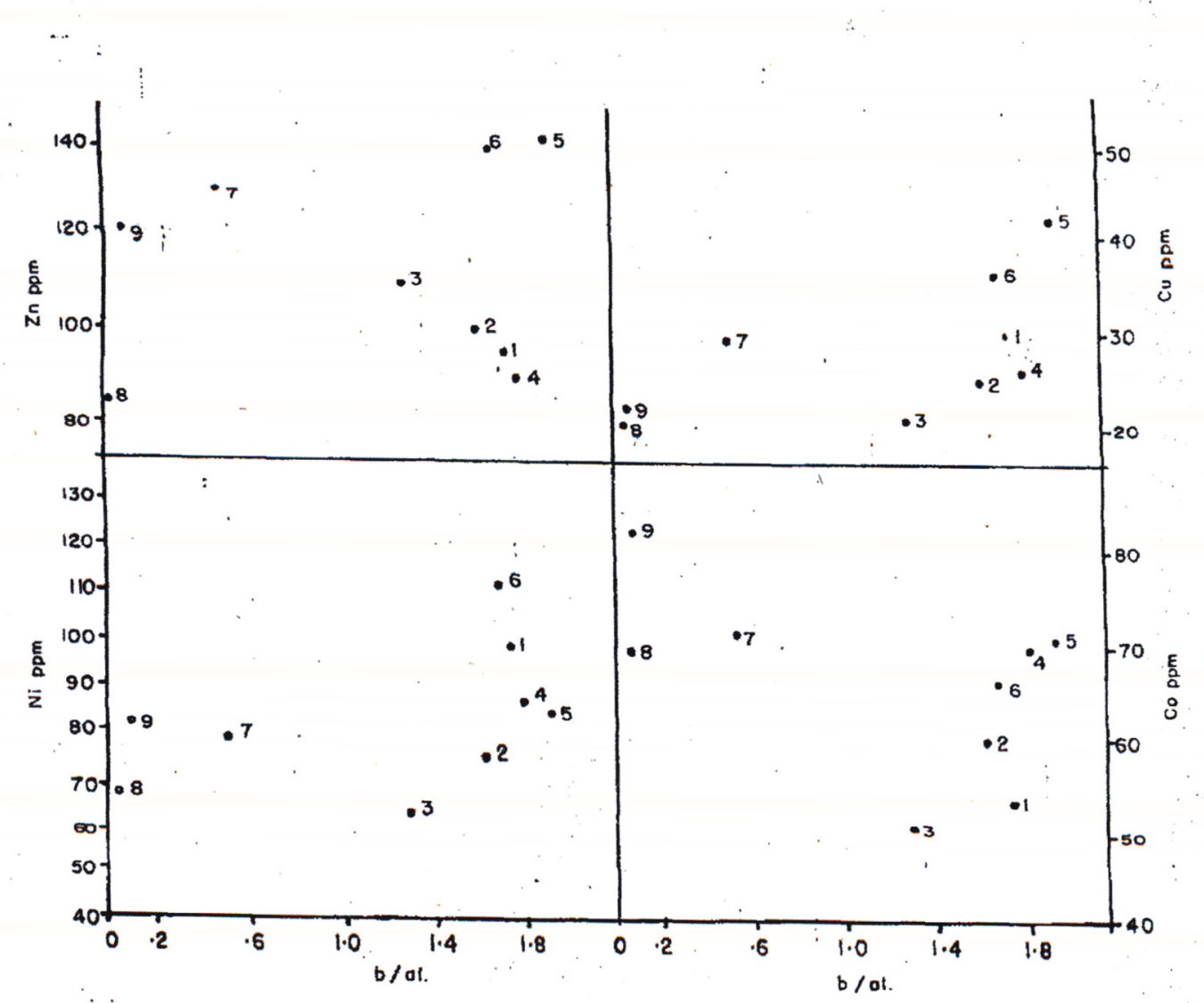

Fig, 7 Plots of trace elements rs bases / alumina ratio. 